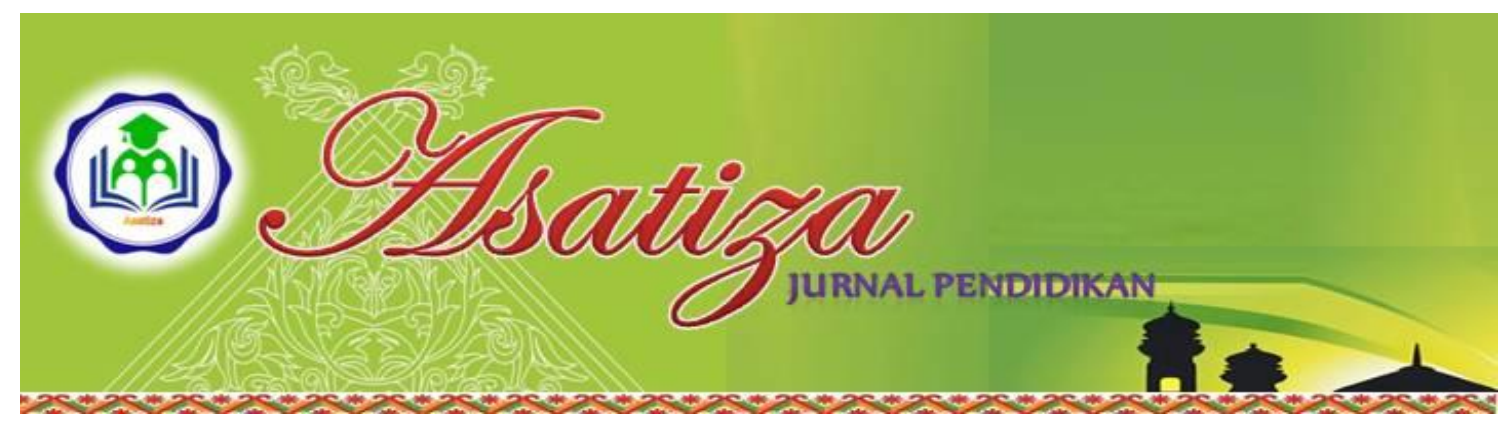

\title{
PENGARUH PENGGUNAAN MEDIA POWERPOINT \\ TERHADAP KREATIVITAS MENGAJAR GURU \\ PADA MATA PELAJARAN PENDIDIKAN AGAMA ISLAM \\ DI SEKOLAH MENENGAH KEJURUAN NEGERI 1 TEMBILAHAN
}

\author{
Iki Nurjanah ${ }^{1}$ \\ ${ }^{1}$ STAI Auliaurrasyidin Tembilahan
}

\section{Abstrak}

Tujuan dari penelitian ini yaitu untuk mendapatkan gambaran impiris tentang penggunaan media powerpoint dan pengaruhnya terhadap kreativitas mengajar guru pada mata pelajaran pendidikan agama Islam di Sekolah Menengah Kejuruan Negeri 1 Tembilahan.

Permasalahan yang diteliti dalam penelitian ini yaitu mengkaji tentang penggunaan media powerpoint dan pengaruhnya terhadap kreativitas mengajar guru pada mata pelajaran pendidikan agama Islam di Sekolah Menengah Kejuruan Negeri 1 Tembilahan.

Subjek dalam penelitian ini adalah 2 orang guru PAI SMK Negeri 1 Tembilahan, Objeknya yaitu pengaruh penggunaan media powerpoint terhadap kreativitas mengajar guru pada mata pelajaran pendidikan agama Islam di Sekolah Menengah Kejuruan Negeri 1 Tembilahan. Jenis penelitian ini adalah penelitian deskriptif kuantitatif dengan teknik pengumpulan data yang gunakan adalah observasi, wawancara dan dokumentasi.

Hasil dari penelitian yang dilakukan, diperoleh $F_{\text {hitung }}>F_{\text {tabel }}=0,50>0$ bahwa terdapat Pengaruh yang signifikan antara penggunaan media powerpoint terhadap kreativitas mengajar guru pada mata pelajaran pendidikan agama Islam di Sekolah Menengah Kejuruan Negeri 1 Tembilahan.

Kata Kunci: Media Power Point, Kreativitas mengajar.

\section{A. PENDAHULUAN}

\section{Latar Belakang}

Teknologi merupakan istilah yang luas berkaitan dengan pemanfaatan dan pengetahuan tentang perkakas dan keterampilan $^{1}$

Penggunaan teknologi dalam dunia pendidikan merupakan alternatif untuk meningkatkan kuantitas dan kualitas hasil pendidikan serta proses yang meliputi sumber-sumber bahan belajar, dimana guru dan peserta didik dituntut untuk aktif menggunakan teknologi pendidikan dalam proses pembelajaran.

Menurut M. Musfiqon dan Andiek Widodo dalam bukunya yang berjudul Desain Presentasi Pembelajaran Inovatif mengatakan bahwa "Pembelajaran adalah proses, cara, atau perbuatan untuk
${ }^{1}$ Sharon E. Smaldino, dkk, Instructional Teachnology \& Media for Learning: Teknologi
Pembelajaran dan Media untuk Belajar, (Jakarta: Prenada Media Group, 2011), hlm.4. 
menjadikan orang atau makhluk hidup menjadi belajar."2

Menurut M. Musfiqon dan Andiek Widodo dalam bukunya yang berjudul Desain Presentasi Pembelajaran Inovatif mengatakan bahwa dalam Permendikbud Nomor 103 Tahun 2014 tentang Pembelajaran pada Pendidikan Dasar dan Pendidikan Menengah disebutkan: "Pembelajaran adalah proses interaksi antar peserta didik, antara peserta didik dengan tenaga pendidik dan sumber belajar pada suatu lingkungan belajar." 3

Pemerintah telah menyadari bahwa peran media dalam proses pembelajaran sangat penting. Oleh karena itu, telah banyak dana diinvestasikan untuk meningkatkan mutu pendidikan dengan melalui penyaluran atau pendistribusian berbagai macam media pembelajaran ke sekolah-sekolah di seluruh Indonesia.

Berdasarkan pendapat di atas dapat disimpulkan bahwa pembelajaran adalah proses interaksi peserta didik dengan pendidik dan sumber belajar pada suatu lingkungan belajar yang meliputi guru dan siswa yang saling bertukar informasi. Menurut Azhar Arsyad mengungkapkan bahwa "Salah satu fungsi utama media pembelajaran adalah sebagai alat bantu mengajar yang turut mempengaruhi iklim, kondisi, dan lingkungan belajar yang ditata dan diciptakan oleh guru."4

Melalui pendekatan teknologi pendidikan, media pembelajaran menjadi daya tarik bagi dunia pendidikan. Ia tidak hanya sebagai alat bantu, tetapi juga sebagai alat penyalur pesan-pesan pendidikan. Walaupun tanpa bantuan guru, media pendidikan dapat menghadapi siswa dalam belajar di kelas dengan demikian, guru tidak

${ }^{2}$ M. Musfiqon dan Andiek Widodo, Desain Presentasi Pembelajaran Inovatif, (Jakarta: Prestasi Pustakaraya, 2015), hlm. 7.

${ }^{3}$ Loc. Cit. boleh berpandangan sebagai satu-satunya sumber belajar, karena sumber belajar lainnya seperti buku teks pelajaran, lingkungan, media cetak, dan media elektronik dapat berperan dalam proses pembelajaran.

Penggunaan media pembelajaran dalam proses belajar mengajar dapat membantu kelancaran, efektivitas dan efisiensi pencapaian tujuan pembelajaran guna memperoleh hasil belajar yang maksimal. Media pembelajaran merupakan salah satu komponen yang tidak bisa diabaikan dalam pengembangan sistem pengajaran yang sukses. Bahan pembelajaran yang dimanipulasikan dalam bentuk media pembelajaran dapat menjadikan peserta didik belajar sambil bermain dan bekerja. Penggunaan suatu media pembelajaran dalam proses belajar mengajar akan lebih menyenangkan siswa dan tentu pengajaran akan lebih bermakna.

Menurut Deni Darmawan di dalam bukunya Pendidikan Teknologi Informasi dan Komunikasi Teori dan Aplikasi menyebutkan dalam membangun sebuah program pembelajaran interaktif berbasis komputer atau dalam konteks multimedia, sebetulnya sangat banyak software yang dapat dimanfaatkan. Mulai dari software yang termasuk ke dalam kelompok programming tools, macromedia, web bahkan yang berbasis windows office sekalipun pada dasarnya dapat dimanfaatkan untuk memproduksi sebuah pembelajaran multimedia atau $C A I .^{5}$

Para guru tidak lagi di batasi oleh halangan ruang kelas karena salah satu kemajuan terbaru dalam teknologi adalah kemampuan menyimpan informasi dalam

${ }^{4}$ Azhar Arsyad, Media Pembelajaran, (Jakarta: Rajagrafindo Persada, 2009), hlm. 15.

${ }^{5}$ Deni Darmawan, Teknologi Pembelajaran, (Bandung: PT. Remaja Rosdakarya, 2012), hlm. 161. 
format digital. Informasi ini mencakup teks, audio, visual, dan film.

Guru dituntut kreatif dan terampil dalam menggunakan produk informasi khususnya berupa komputer pada mata pelajaran pendidikan agama Islam. Untuk mencapai tujuan tersebut, seorang guru seharusnya mulai menyadari pentingnya aspek teknologi untuk meningkatkan hasil belajar, salah satunya dengan mengolah materi pembelajaran melalui pemanfaatan komputer khususnya menggunakan aplikasi microsoft powerpoint.

Berdasarkan pengamatan yang penulis lakukan di SMK Negeri 1 Tembilahan ditemukan beberapa gejala sebagai berikut: Masih ada guru Pendidikan Agama Islam yang kurang terampil dalam mengolah materi pembelajaran dengan memanfaatkan media powerpoint., Kurangnya sarana pendukung pembelajaran seperti proyektor $L C D$., Dalam menyampaikan materi pembelajaran pada umumnya guru terfokus pada teks yang ada dalam media powerpoint yang ditampilkan., Menyampaikan materi pembelajaran melalui penggunaan media powerpoint membuat siswa malas menulis disebabkan karena animasi yang berlebihan.

Adapun yang menjadi Rumusan masalah dalam penelitian ini adalah: Bagaimana penggunaan media powerpoint pada mata pelajaran Pendidikan Agama Islam di Sekolah Menengah Kejuruan Negeri 1 Tembilahan? Bagaimana kreativitas mengajar guru pada mata pelajaran Pendidikan Agama Islam? dan Apakah ada pengaruh penggunaan media powerpoint terhadap kreativitas mengajar guru pada mata pelajaran Pendidikan

\footnotetext{
${ }^{6}$ Azhar Arsyad, Op. Cit, hlm. 3.

${ }^{15}$ Daryanto, Media Pembelajaran Peranannya Sangat Penting Dalam Mencapai Tujuan Pembelajaran, (Yogyakarta: Gava Media, 2012), hlm. 4.
}

Agama Islam di Sekolah Menengah Kejuruan Negeri 1 Tembilahan?

\section{Media Power Point dalam Pembelajaran}

Kata media berasal dari bahasa latin medius yang secara harfiah berarti 'tengah','perantara' atau 'pengantar'. Dalam bahasa Arab media adalah perantara (وَسَاِئل) atau pengantar pesan dari pengirim kepada penerima pesan. ${ }^{6}$ "Menurut Drs. Daryanto media merupakan salah satu komponen komunikasi yaitu sebagai pembawa pesan dari komunikator menuju komunikan."7 Sedangkan menurut Martin dan Briggs "Media adalah semua sumber yang diperlukan untuk melakukan kumunikasi dengan siswa."

Komputer sebagai salah satu produk teknologi canggih dipandang mampu menjawab tantangan pengembangan pembelajaran yang efektif, efisien dan menarik. Azhar Arsyad menyebutkan dalam bukunya bahwa Dewasa ini komputer memiliki fungsi yang berbedabeda dalam bidang pendidikan dan latihan. Komputer berperan sebagai manajer dalam proses pembelajaran yang dikenal dengan nama Computer-Managed Instruction (CMI). Ada pula peran komputer sebagai pembantu tambahan dalam belajar; pemanfaatannya meliputi penyajian informasi isi materi pelajaran, latihan, atau kedua-duanya. ${ }^{9}$

Salah satu terobosan yang dapat digunakan dalam rangka meningkatkan kualitas pembelajaran pendidikan agama Islam adalah penggunaan media komputer. penggunaan komputer sebagai sarana pembelajaran dapat memberikan

${ }^{8}$ Made Wena, Strategi Pembelajaran Inovatif Kontemporer Suatu Tinjauan Konseptual Operasional, (Jakarta: Bumi Aksara, 2011), hlm. 9.

\footnotetext{
${ }^{9}$ Azhar Arsyad, Op.Cit., hlm. 96.
} 
pengaruh yang sangat positif karena memiliki sifat yang representative dan interaktif. Misalnya dengan menggunakan media powerpoint, guru dapat menyajikan materi dengan animasi, menambahkan video dan lain sebagainya. Kelebihan itu dapat mengaktifkan fungsi kognisi, afeksi dan sensorik siswa. Untuk penyajian materi yang maksimal, guru membutuhkan ketersediaan serta keahlian dalam mengoperasionalkan jenis media yang berbeda. Penggunaan berbagai jenis media dalam satu rangkaian presentasi disebut presentasi multimedia. Presentasi dalam bagian ini dipahami sebagai bagian dari langkah kegiatan pembelajaran.

Aplikasi multimedia dalam presentasi dapat menjadikan pembelajaran lebih menarik, powerfull, interaktif, efektif, efisien, serta kualitas pembelajaran lebih terjaga. Dengan menggunakan multimedia, guru dapat menampilkan materi atau peristiwa yang komplek sehingga terjadi produktivitas pembelajaran yang maksimal.

Kegiatan belajar mengajar dikatakan berhasil apabila dalam penyampaian materi kepada siswa dengan tingkat ketuntasan yang maksimal. Jika tidak, presentase materi yang diterima oleh siswa harus lebih banyak dibandingkan dengan tidak menggunakan media presentasi multimedia. Ingatlah teori belajar, penyajian saja tidaklah cukup. Audiens memerlukan penguatan (reinforcement), bahkan perlu pengayaan dalam belajar. Hadirnya multimedia sangatlah membantu audiens untuk memahami materi dengan tuntas. ${ }^{10}$ "Menurut Budi Permana, dalam bukunya 36 Jam Belajar Komputer Microsoft

${ }^{10}$ M. Musfiqon dan Andiek Widodo, Op.Cit., hlm. 39 .

${ }^{11}$ Budi Permana, Op.Cit., hlm. 1.

${ }^{12}$ Pengertian dan Sejarah Microsoft Power Point,
Office Powerpoint 2003 menyatakan bahwa Powerpoint atau yang disebut Microsoft Powerpoint merupakan program aplikasi yang paling populer dan paling banyak digunakan saat ini. Dalam menggunakan microsoft powerpoint dalam merancang dan membuat presentasi profesional dengan mudah dan cepat." 11

Microsoft Powerpoint merupakan sebuah software yang dibuat dan dikembangkan oleh perusahaan Microsoft, dan merupakan salah satu program berbasis multimedia. Di dalam komputer, biasanya program ini sudah dikelompokkan dalam program Microsoft Office. Program ini dirancang khusus untuk menyampaikan presentasi dengan beberapa fitur menu yang mampu menjadikannya sebagai media komunikasi yang menarik.

Diterangkan di dalam artikel Irwan Adi Gunawan yang diunggah dari google Aplikasi Microsoft PowerPoint ini pertama kali dikembangkan oleh Bob Gaskins dan Dennis Austin sebagai Presenter untuk perusahaan bernama Forethought, Inc yang kemudian mereka ubah namanya menjadi Powerpoint. Pada tahun 1987, PowerPoint versi 1.0 dirilis, dan komputer yang didukungnya adalah Apple Macintosh. PowerPoint kala itu masih menggunakan warna hitam/putih, yang mampu membuat halaman teks dan grafik untuk transparansi overhead projector (OHP). Setahun kemudian, versi baru dari PowerPoint muncul dengan dukungan warna, setelah Macintosh berwarna muncul ke pasaran. ${ }^{12}$

Powerpoint berarti poin yang memiliki kekuatan. Media pembelajaran dengan menggunakan powerpoint tidak

https://irwanadigunawan4.wordpress.com/2013/ 10/31/penger tian-dan-sejarah-microsoft-powerpoint/, dalam www.google.com, pada hari Minggu, 8 Januari 2016, pukul 17.36 WIB 
memuat hal yang detail, namun penjelasan yang detail adalah tugas guru. Artinya dalam menggunakan media powerpoint maka yang dimuat dalam slide harus benar-benar poin dari materi yang disampaikan.

Microsoft Office powerpoint pada pola penyajian ini digunakan sebagai alat bantu bagi guru untuk menyampaikan materi dan kontrol pembelajaran terletak pada guru. Beberapa hal yang menjadikan media ini menarik untuk digunakan sebagai media pembelajaran adalah berbagai kemampuan pengolahan teks, warna, dan gambar, serta animasi-animasi yang bisa diolah sendiri sesuai kreatifitas guru. Pada prinsipnya program ini terdiri dari beberapa unsur rupa dan pengontrolan operasionalnya.

Unsur rupa yang dimaksud terdiri dari slide, teks, gambar dan bidang-bidang warna yang dapat dikombinasikan dengan latar belakang yang telah tersedia. Unsur rupa tersebut dapat dibuat tanpa gerak atau dibuat dengan gerakan tertentu sesuai keinginan guru. Seluruh tampilan dari program powerpoint dapat di atur sesuai keperluan, apakah akan berjalan sendiri sesuai timing yang ditentukan atau berjalan secara manual dengan mengklik tombol mouse. Jika digunakan untuk menyampaikan materi pembelajaran yang mementingkan terjadinya interaksi antara guru dan siswa maka kontrol operasinya harus menggunakan cara manual.

\section{Langkah-Langkah Penggunaan Media Powerpoint}

Menurut M. Musfiqon dan Andiek Widodo, dalam bukunya Desain Presentasi Pembelajaran Inovatif, struktur presentasi yang baik akan memberikan pengaruh yang bagus dan menunjang hlm. 51 . tercapainya tujuan presentasi materi pembelajaran. ${ }^{13}$ Maka perlu bagi seorang guru yang menggunakan media Powerpoint memperhatikan tiga langkah berikut ini:

a. Tahap Persiapan presentasi media Powerpoint

1) Penyampaian pesan secara runtut Materi yang akan disampaikan perlu diurutkan secara runtut. Menurut $\mathrm{M}$. Musfiqon dan Andiek Widodo mengatakan bahwa "langkah ini dilakukan agar materi yang tersaji sesuai dengan cara berpikir logis dan sistematis." 14 Materi yang disajikan secara runtut dan logis akan membantu peserta didik cepat memahami materi pelajaran.

2) Fokus pada ide-ide utama

Pada saat akan memberikan materi pembelajaran guru harus mempersiapkan terlebih dahulu ide utama dalam slide powerpoint yang akan dipresentasikan. Guru boleh melakukan penguatan dengan berbagai langkah. Apapun kondisi yang terjadi tugas utama guru sudah berhasil menyampaikan ide utama yang menjadi ukuran sukses atau tidaknya pembelajaran.

3) Membuat peserta didik lebih mudah memahami materi

Tingkat keterserapan materi seringkali tidak sama antara audiens satu dengan audiens yang lain. Kondisi ini pasti dipengaruhi berbagai faktor, baik internal maupun eksternal audiens. ${ }^{15}$ Tugas guru adalah meminimalisir faktor eksternal yang menyebabkan peserta didik sulit memahami materi pembelajaran. Guru harus memastikan manajemen kelas, suara yang membuat bias, visualisasi yang mengganggu

\footnotetext{
${ }^{14}$ Loc.Cit

${ }^{15}$ Ibid., hlm. 52.
} 
konsentrasi peserta didik, serta media pembelajaran yang memadai. Memudahkan peserta didik untuk memahami materi dapat dilakukan dengan memberikan contoh, mempraktikkan, serta mendesain pengalaman belajar yang lebih bermakna. "Ukuran berhasil atau tidaknya presentasi dilihat dari tingkat pemahaman peserta terhadap materi yang disampaikan." 16

\section{b. Tahap Pembukaan}

1) Mengkondisikan Peserta Didik

Ketika seorang guru ingin menyampaikan informasi maka yang pertama menarik perhatian peserta didik, ketika mereka berada dalam kondisi siap untuk belajar, maka dapat dilakukan tahap berikutnya.

2) Menjelaskan tujuan pembelajaran

Menjelaskan tujuan pembelajaran ini bertujuan menumbuhkan minat peserta didik untuk terus memperhatikan dan mengikuti setiap materi yang akan disampaikan.

3) Memberikan motivasi kepada peserta didik

Guru harus mendesain bagaimana pembukaan yang berkesan dan menarik perhatian peserta didik agar termotivasi untuk mengikuti keseluruhan pembelajaran dengan penuh perhatian. Seorang guru mempunyai daya kreasi yang kuat untuk membuat peserta didik bersemangat untuk belajar. "Menurut Rudi Susilana dan Cepi Riyana rancangan isi dan desain

\footnotetext{
${ }^{16}$ Ibid., hlm. 53.

${ }^{17}$ Rudi Susilana dan Cepi Riyana, Media Pembelajaran, Hakikat Pengembangan,
}

multimedia interaktif (teks, grafis, animasi, dan audio/video) yang serasi dapat menumbuhkan motivasi belajar peserta didik." 17

\section{c. Kegiatan Inti}

1) Menjelaskan Materi Utama

Slide yang sederhana adalah slide yang memuat pesan utama, desain menarik, dan tampilan tidak terlalu banyak aksesoris. Dengan hanya menyajikan poinpoin penting dalam presentasi akan menjadikan sajian slide mudah diingat oleh peserta didik dalam waktu singkat. Seorang guru yang menyajikan media powerpoint juga diharapkan memperhatikan beberapa hal berikut ini:

a) Panjang teks yang disajikan dalam program harus singkat, jelas dan padat.

b) Pembuatan grafik dan animasi ditujukan untuk menambah pemahaman dan pemusatan perhatian siswa terhadap materi yang disajikan dalam program tutorial.

c) Penggunaan warna yang sesuai akan berguna untuk menarik dan memfokuskan perhatian siswa, baik itu komposisi warna maupun kekontrasannya. ${ }^{18}$

2) Memberikan penguatan dan pengayaan

Jangan lupa, setiap 15 menit perhatian peserta didik akan menurun. Jangan paksakan dengan terus menjelaskan, hiasi dengan penguatan dan pengayaan, baik dengan game, Ice breaking, atau penguatan lainnya yang ada nuansa refresh suasana. Untuk pengayaan diberikan sedikit

Pemanfaatan dan Penilaian, (Bandung: CV. Wacana Prima, 2008), hlm. 130.

${ }^{18}$ Ibid., hlm. 152. 
pengetahuan yang lebih luas berkaitan dengan masalah kehidupan nyata yang dihubungkan dengan materi yang disajikan, biasa berupa video, gambar dan lain sebagainya.

\section{d. Penutupan}

1) Memberikan umpan balik Umpan balik adalah kondisi psikologis peserta didik dan guru yang terjadi dalam kegiatan belajar mengajar yang terlihat dalam sikap, gerak gerik, respons, dan perubahan lainnya yang terjadi pada guru dan murid. ${ }^{19}$

2) Menyimpulkan materi secara bersama-sama

Pemateri harus dapat melakukan penguatan dan meringkas esensi materi yang disampaikan dengan singkat, padat dan jelas sehingga mudah diingat. ${ }^{20}$

\section{Kelebihan dan Kekurangan Media Powerpoint}

Penggunaan program ini memiliki kelebihan sebagai berikut:

a. Memberi kesempatan kepada siswa untuk memecahkan masalah secara individual.

b. Menyedikan presentasi yang menarik dengan animasi.

c. Menyediakan pilihan isi pembelajaran yang banyak dan beragam.

d. Mampu membangkitkan motivasi siswa dalam belajar.

e. Mampu mengaktifkan dan menstimulasi metode mengajar dengan baik. f. Meningkatkan pengembangan pemahaman siswa terhadap materi yang disajikan.

g. Merangsang siswa belajar dengan penuh semangat, materi yang disajikan mudah dipahami oleh siswa.

h. Siswa mendapat pengalaman yang bersifat konkret, retensi siswa meningkat.

i. Memberi umpan balik secara langsung.

j. Siswa dapat menentukan sendiri laju pembelajaran.

k. Siswa dapat melakukan evaluasi diri. ${ }^{21}$

Adapun kekurangan media powerpoint, yaitu:

a. Pengadaannya mahal, dan tidak semua sekolah dapat memiliki, Sebab membutuhkan alat lain seperti LCD, Laptop, dll.

b. Jika tampilan fisik isi tidak dirancang dengan baik atau hanya merupakan tampilan seperti dibuku teks biasa, pembelajaran melalui media tersebut tidak akan mampu meningkatkan motivasi, perhatian belajar siswa.

c. Guru yang tidak memahami aplikasi program komputer tidak dapat merancang pembelajaran lewat media komputer, ia harus bekerja sama dengan ahli programer komputer grafis, juru kamera, dan teknisi komputer. ${ }^{22}$.

\section{Kreativitas Mengajar Guru}

Dari berbagai faktor yang berpengaruh terhadap efektivitas pembelajaran, nampaknya faktor guru perlu mendapat perhatian yang pertama dan utama, disamping kurikulumnya, karena baik buruknya suatu kurikulum (pembelajaran)

\footnotetext{
${ }^{20}$ M. Musfiqon dan Andiek Widodo, Op.Cit., hlm. 55

${ }^{21}$ Made Wena, Op.Cit., hlm. 204.

${ }^{22}$ Ibid., hlm. 205.
}

Strategi Pembelajaran, (Jakarta: Prenadamedia Group, 2009), hlm. 324. 
pada akhirnya bergantung pada kreativitas

guru dalam menjabarkan dan merealisasikan kurikulum tersebut. Pembelajaran yang efektif menekankan pada bagaiman agar peserta didik mampu belajar. Melalui kreativitas guru, pembelajaran di kelas menjadi sebuah aktivitas yang menyenangkan. Proses pembelajaran yang menyenangkan tentunya tidak tercipta begitu saja akan tetapi pengelolaannya dirancang oleh guru dengan penggunaan media sehingga aktivitas pembelajaran siswa menjadi dipermudah dan mendorong proses belajar siswa.

Menurut Kamus umum Bahasa Indonesia, Kreativitas diartikan sebagai kemampuan untuk mencipta, atau daya cipta, atau sesuatu yang berkaitan dengan perihal berkreasi. ${ }^{23}$ Kreativitas adalah sikap kreatif dan terampil serta inovatif dalam mengelola suatu objek.

Guru merupakan profesi/ jabatan atau pekerjaan yang memerlukan keahlian khusus sebagai guru. Jenis pekerjaan ini tidak dapat dilakukan oleh sembarang orang diluar bidang pendidikan. Tugas guru sebagai profesi meliputi mendidik, mengajar, dan melatih. Mendidik berarti meneruskan dan mengembangkan nilainilai hidup. Mengajar berarti meneruskan dan mengembangkan ilmu pengetahuan dan teknologi. Sedangkan melatih berarti mengembangkan keterampilanketerampilan pada siswa ${ }^{24}$, maka dari itu profesi ini diperlukan kreativitas yang sangat tinggi.

Mengajar pada umumnya adalah suatu kegiatan yang bukan menyangkut masalah penelitian. $^{25}$ Mengajar sendiri dapat

${ }^{23}$ Departemen Pendidikan Nasional, Op.Cit., hlm. 817.

${ }^{24}$ M. Uzer Usman, Menjadi Guru Profesional, (Bandung: PT. Remaja Rosdakarya, 2010), hlm. 6. diartikan sebagai membimbing kegiatan belajar siswa sehingga ia mau belajar. ${ }^{26}$ Selain itu mengajar juga merupakan penyampaian pengetahuan dan kebudayaan kepada siswa. Dengan demikian tujuannya pun hanya berkisar sekitar pencapaian penguasaan siswa atas sejumlah pengetahuan dan kebudayaan. ${ }^{27}$

Dari uraian di atas dapat disimpulkan bahwa kreativitas mengajar guru adalah sikap kreatif, terampil, dan inovatif dalam melaksanakan pengajaran untuk pencapaian tujuan pembelajaran.

\section{Bentuk Kreativitas Mengajar Guru}

Bentuk kreativitas mengajar seorang guru tercermin pada ciri-ciri dari kreativitas itu sendiri. Menurut Sund sebagaimana yang dikutip oleh Slameto dalam buku Belajar dan Faktor-Faktor Yang Mempengaruhinya bahwa ciri-ciri dari kreativitas adalah:

a. Hasrat keingintahuan yang cukup besar

b. Bersikap terbuka terhadapt pengalaman baru

c. Panjang akal

d. Keinginan untuk menemukan dan meneliti

e. Cenderung lebih menyukai tugas yang berat dan sulit

f. Cenderung mencari jawaban yang luas dan memuaskan

g. Memiliki dedikasi bergairah serta aktif dalam melaksanakan tugas

h. Berpikir fleksibel

i. Menanggapi pertanyaan yang diiajukan serta cenderung memberi jawaban lebih banyak

\footnotetext{
${ }^{25}$ Zakiah Daradjat, dkk, Metodik Khusus Pengajaran Agama Islam, (Jakarta: Bumi Aksara, 2004), hlm. 14.

${ }^{26}$ Ibid., hlm. 21.

27 Muhibbin Syah, Psikologi Pendidikan Dengan Pendekatan Baru, Op. Cit., hlm. 181.
} 
j. Kemampuan membuat analisis dan sintesis

k. Memiliki semangat bertanya serta meneliti

1. Memiliki daya abstrak yang cukup baik

m. Memiliki latar belakang membaca yang cukup luas. ${ }^{28}$

\section{Ciri-Ciri Kreativitas Mengajar Guru}

Menurut Fita Nur Arifah dalam bukunya Menjadi Guru Teladan, Kreatif, Inspiratif, Motivatif \& Profesional, guru kreatif dapat diartikan sebagai guru yang tidak pernah puas dengan apa yang disampaikan kepada peserta didik. Guru yang kreatif selalu berusaha menemukan cara-cara baru untuk menemukan potensi unik siswanya. Baginya, setiap tahun harus ada kreativitas yang dikembangkan dalam dirinya. Sehingga materi yang disampaikan tidak merupakan materi hafalan dari tahun ke tahun. ${ }^{29}$ Ciri-ciri guru yang kreatif dalam mengajar adalah sebagai berikut:

a. Menyampaikan Ide atau Pemikiran Materi yang disampaikan kepada siswa harus berasal dari ide atau pemikiran guru yang nantinya akan dipecahkan secara bersama-sama dengan peserta didik.

b. Mengubah Cara Bertanya Kepada Peserta Didik. Memberikan pertanyaan kepada peserta didik adalah bagian dari cara guru memastikan apakah peserta didik memahami atau tidak. Selama ini yang guru lakukan ketika bertanya adalah mengharapkan siswa segera menjawab, jika tidak maka guru akan mengubah pertanyaan. ${ }^{30}$

\footnotetext{
${ }^{28}$ Slameto, Belajar dan Faktor-Faktor Yang Mempengaruhinya, (Jakarta: PT. Asdi Mahasatya, 2003), hlm. 147.
}

c. Memberikan Tema yang Survival Kepada Peserta Didik. Tema yang bersifat menantang sangat banyak. Guru yang kreatif dituntut untuk melibatkan seluruh peserta didik dalam mengatasi permasalahan tersebut.

d. Mengkondisikan Ruang Kelas Seperti Ruang Diskusi. Guru yang kreatif harus mengkondisikan ruang kelas seperti ruang kelas diskusi yang produktif.

e. Memastikan Semua Ide Diterima. Kelas yang baik akan menghargai hasil pemikiran bersama, bahkan jika ide tersebut di luar pemikiran lazim guru.

\section{B. METODOLOGI}

Jenis penelitian ini adalah penelitian deskriptif kuantitatif yaitu penelitian yang bertujuan untuk menjelaskan fenomena yang ada dengan menggunakan angga-angka. Penelitian ini dilaksanakan disalah satu lembaga pendidikan yaitu di Sekolah Menengah Kejuruan Negeri 1 Tembilahan. subjek dalam penelitian ini adalah guru mata pelajaran pendidikan agama Islam menggunakan media powerpoint yang berjumlah 2 orang, Adapun objek dalam penelitian ini adalah pengaruh penggunaan media power point terhadap kreativitas mengajar siswa pada mata pelajaran pendidikan agama Islam. Data dalam penelitian ini dikumpulkan dengan menggunakan

\footnotetext{
${ }^{29}$ Fita Nur Arifah, Menjadi Guru Teladan, Kreatif, Inspiratif, Motivatif \& Profesional, (Yogyakarta: Araska, 2016), hlm. 80.

${ }^{30}$ Ibid., hlm. 96
} 
teknik atau metode sebagai berikut: observasi dan dokumentasi.

Untuk menguji variabel $\mathrm{X}$ dan variabel $\mathrm{Y}$ maka penulis dalam menganalisa data menggunakan teknik kuantitatif dengan menggunakan rumus Regresi.

\section{PEMBAHASAN}

Untuk memudahkan penulis dalam menganalisis data, maka penulis sajikan hasil observasi penggunaan media powerpoint dari tabel IV.5-IV.10 dan observasi kreativitas mengajar guru dari tabel IV.11-IV.16, ke dalam rekapitulasi hasil observasi. Rekapitulasi hasil observasi dapat dilihat pada tabel berikut:

Rekapitulasi Observasi Penggunaan Media Powerpoint di SekolaH Menengah Kejuruan Negeri 1 Tembilahan

\begin{tabular}{|c|c|c|c|c|c|c|}
\hline \multirow{3}{*}{$\begin{array}{l}\mathbf{N} \\
\mathbf{O}\end{array}$} & \multirow{3}{*}{$\begin{array}{l}\text { NA } \\
\text { MA }\end{array}$} & \multirow{3}{*}{$\begin{array}{c}\text { OBSER } \\
\text { VASSI }\end{array}$} & \multicolumn{4}{|c|}{ OPTION PILIHAN } \\
\hline & & & \multicolumn{2}{|c|}{ YA } & \multicolumn{2}{|c|}{ TIDAK } \\
\hline & & & $\mathbf{F}$ & $\%$ & $\mathrm{~F}$ & $\%$ \\
\hline \multirow[t]{3}{*}{1} & \multirow{3}{*}{$\begin{array}{c}\text { Gur } \\
\text { u } \\
\text { PAI } \\
\text { I }\end{array}$} & Pertama & 9 & 81,8 & 2 & 18,2 \\
\hline & & Kedua & 10 & 90,9 & 1 & 9,1 \\
\hline & & Ketiga & 10 & 90,9 & 1 & 9,1 \\
\hline \multirow[t]{3}{*}{2} & \multirow{3}{*}{$\begin{array}{c}\text { Gur } \\
\mathrm{u} \\
\text { PAI } \\
\text { II }\end{array}$} & Pertama & 9 & 81,8 & 2 & 18,2 \\
\hline & & Kedua & 9 & 81,8 & 2 & 18,2 \\
\hline & & Ketiga & 9 & 81,8 & 2 & 18,2 \\
\hline \multicolumn{3}{|c|}{ Jumlah } & 56 & 84,8 & 10 & 15,2 \\
\hline
\end{tabular}

Rekapitulasi Observasi Kreativitas Mengajar Guru di Sekolah Menengah Kejuruan Negeri 1 Tembilahan

\begin{tabular}{|c|c|c|c|c|c|c|}
\hline \multirow{2}{*}{ N } & \multirow{2}{*}{ NA } & \multirow{2}{*}{ OBSER } & \multicolumn{3}{|c|}{ OPTION PILIHAN } \\
\cline { 3 - 7 } & MA & VASI & \multicolumn{2}{|c|}{ YA } & \multicolumn{2}{c|}{ TIDAK } \\
\cline { 3 - 7 } & & & F & $\%$ & F & $\%$ \\
\hline 1 & Gur & Pertama & 4 & 80 & 1 & 20 \\
\cline { 3 - 7 } & u & Kedua & 4 & 80 & 1 & 20 \\
\cline { 3 - 7 } & PAI & Ketiga & 5 & 100 & 0 & 0 \\
\hline 2 & Gur & Pertama & 4 & 80 & 1 & 20 \\
\cline { 4 - 7 } & u & Kedua & 4 & 80 & 1 & 20 \\
\hline
\end{tabular}

\begin{tabular}{|c|c|c|c|c|c|c|}
\hline $\begin{array}{c}\text { PAI } \\
\text { II }\end{array}$ & Ketiga & 4 & 80 & 1 & 20 \\
\hline \multicolumn{2}{|c|}{ Jumlah } & $\mathbf{2 5}$ & $\mathbf{8 3}$ & 5 & 17 \\
\hline
\end{tabular}

TABEL PENOLONG

\begin{tabular}{|c|c|c|c|c|c|}
\hline No & $\mathbf{X}$ & $\mathbf{Y}$ & $\mathbf{X}^{\mathbf{2}}$ & $\mathbf{Y}^{\mathbf{2}}$ & $\mathbf{X Y}$ \\
\hline 1 & 29 & 13 & 841 & 169 & 377 \\
\hline 2 & 27 & 12 & 729 & 144 & 324 \\
\hline Statistik & $\sum \mathbf{X}$ & $\sum \mathbf{Y}$ & $\sum \mathbf{X}^{\mathbf{2}}$ & $\sum \mathbf{Y}^{\mathbf{2}}$ & $\sum \mathbf{X Y}$ \\
\hline Jumlah & $\mathbf{5 6}$ & $\mathbf{2 5}$ & $\mathbf{1 5 7 0}$ & $\mathbf{3 1 3}$ & $\mathbf{7 0 1}$ \\
\hline
\end{tabular}

1. Menghitung nilai $\mathrm{b}$ dan nilai a dengan rumus:

$$
\begin{aligned}
& \mathrm{b}=\frac{\mathrm{n} \cdot \Sigma \mathrm{XY}-\Sigma \mathrm{X} \cdot \Sigma \mathrm{Y}}{\mathrm{n} \cdot \Sigma \mathrm{X}^{2}-(\Sigma \mathrm{X})^{2}} \\
& =\frac{2 \cdot 701-56 \cdot 25}{2 \cdot 1570-(56)^{2}} \\
& =\frac{2}{4}=0,50
\end{aligned}
$$

2. Mencari Jumlah Kuadrat Regresi $\left(\mathrm{JK}_{\mathrm{reg}[\mathrm{a}]}\right)$

$$
\begin{aligned}
& J_{K_{\text {reg }[\mathrm{a}]}}=\frac{(\Sigma \mathrm{Y})^{2}}{\mathrm{n}} \\
& =\frac{25^{2}}{2} \\
& =\frac{625}{2} \\
& =312,5
\end{aligned}
$$

3. Mencari Jumlah Kuadrat Regresi $\left(\mathrm{JK}_{\mathrm{reg}[\mathrm{b} \mid \mathrm{a}]}\right)$

$$
\begin{aligned}
& \mathrm{JK}_{\text {Reg[b|a] }}= \mathrm{b} .\left\{\sum \mathrm{XY}-\frac{\left(\sum \mathrm{X}\right) \cdot\left(\sum \mathrm{Y}\right)}{\mathrm{n}}\right\} \\
&= 0,50 .\left\{701-\frac{56 \cdot 25}{2}\right\} \\
&=0,50
\end{aligned}
$$

4. Mencari jumlah kuadrat residu ( $\left.\mathrm{JK}_{\mathrm{Res}}\right)$ dengan rumus

$$
\begin{aligned}
& \mathrm{JK}_{\text {Res }}=\Sigma \mathrm{Y}^{2}-\mathrm{JK}_{\text {Reg[b|a] }-} \mathrm{JK}_{\text {reg[a] }} \\
& =313-0.50-312,5 \\
& =0
\end{aligned}
$$

5. Mencari rata-rata jumlah kuadrat regresi $\left(\mathrm{RJK}_{\mathrm{reg}[\mathrm{a}]}\right)$

$$
\mathrm{RJK}_{\mathrm{reg}[\mathrm{a}]}=\mathrm{JK}_{\mathrm{reg}[\mathrm{a}]}
$$




$$
=312,5
$$

6. Mencari rata-rata jumlah kuadrat $\operatorname{residu}\left(\mathrm{RJK}_{\mathrm{reg}[\mathrm{b} \mid \mathrm{a}]}\right)$

$$
\mathrm{RJK}_{\mathrm{reg}[\mathrm{b} \mid \mathrm{a}]}=\mathrm{JK}_{\mathrm{reg}[\mathrm{b} \mid \mathrm{a}]}
$$

$$
=0,50
$$

7. Mencari rata-rata jumlah kuadrat residu $\left(\mathrm{RJK}_{\mathrm{res}}\right)$

$$
\begin{aligned}
\mathrm{RJK}_{\mathrm{res}}= & \frac{J K_{\text {res }}}{n-2} \\
& =\frac{0}{2-2} \\
& =0
\end{aligned}
$$

8. Menguji signifikansi dengan rumus:

$$
\begin{aligned}
\mathrm{F}_{\text {hitung }}= & \frac{R J K_{\text {reg }[b \mid a]}}{R J K_{\text {res }}} \\
& =\frac{0,50}{0} \\
& =0,50
\end{aligned}
$$

9. Membandingkan Fhitung dengan Ftabel dengan kaidah pengujian signifikan sebagai berikut:

$$
\begin{aligned}
& \mathrm{F}_{\text {tabel }}=\mathrm{F}_{\{(1-} \alpha_{)(\mathrm{dk}=\mathrm{k}-2),(\mathrm{dk} \text { res }=\mathrm{n}-\mathrm{k})\}} \\
& \mathrm{F}_{\{(1-0,05)(\mathrm{dk}=2-2],(\mathrm{dk} \text { res }=2-2)\}} \\
& \mathrm{F}_{\{(0,95)(0,0)\}}
\end{aligned}
$$

Berdasarkan perhitungan dengan rumus di atas dengan $F_{\text {hitung }}$ 0,50 lebih besar dari $\mathrm{F}_{\text {tabel }} 0$, maka terdapat pengaruh yang signifikan antara penggunaan media powerpoint terhadap kreativitas mengajar guru pada mata pelajaran pendidikan agama Islam di Sekolah Menengah Kejuruan Negeri 1 Tembilahan.

Ternyata Pada taraf signifikansi 5\% $\mathrm{F}_{\text {tabel }}=0$, maka dari hasil diatas diperoleh $F_{\text {hitung }}>F_{\text {tabel }}$ atau 0,50 $>0$

Ternyata Pada taraf signifikansi 5\% $\mathrm{F}_{\text {tabel }}=0$, maka dari hasil diatas diperoleh $F_{\text {hitung }}>F_{\text {tabel }}$ atau $0,50>0$
$\mathrm{H}_{0}$ : Tidak terdapat pengaruh yang signifikan antara media powerpoint terhadap kreativitas mengajar guru pada mata pelajaran pendidikan agama Islam di Sekolah Menengah Kejuruan Negeri 1 Tembilahan.

$\mathrm{H}_{\mathrm{a}}$ : Terdapat pengaruh yang signifikan antara media powerpoint terhadap kreativitas mengajar guru pada mata pelajaran pendidikan agama Islam di Sekolah Menengah Kejuruan Negeri 1 Tembilahan.

\section{KESIMPULAN}

Berdasarkan hasil analisis dari hasil yang telah dilakukan maka dapat ditarik kesimpulan bahwa:

1. Penggunaan media powerpoint pada mata pelajaran Pendidikan Agama Islam di Sekolah Menengah Kejuruan Negeri 1 Tembilahan dinilai sangat baik.

2. Adapun kreativitas mengajar guru pada mata pelajaran Pendidikan Agama Islam di Sekolah Menengah Kejuruan Negeri 1 Tembilahan dinilai sangat baik.

3. Berdasarkan hasil penelitian yang dilakukan, maka diperoleh $F_{\text {hitung }}>F_{\text {tabel }}=0,50>0$ berarti terdapat Pengaruh yang signifikan antara penggunaan media powerpoint terhadap kreativitas mengajar guru pada mata pelajaran pendidikan agama Islam di Sekolah Menengah Kejuruan Negeri 1 Tembilahan. 


\section{REFERENSI}

Abuddin Nata, 2009, Perspektif Islam Tentang Strategi Pembelajaran, Jakarta: Prenadamedia Group.

Ahmad Susanto, 2013, Teori Belajar \& Pembelajaran di Sekolah Dasar, Jakarta: Prenada Media Group.

Anas Sudijono, 1996, Pengantar Evaluasi Pendidikan, Jakarta: PT. Raja Grafindo Persada.

Anas Sudijono, 2008, Pengantar Statistik Pendidikan, Jakarta: RajaGrafindo Persada.

Azhar Arsyad, 2009, Media Pembelajaran, Jakarta: Rajagrafindo Persada.

Budi Permana, 2005, 36 Jam Belajar Komputer Microsoft Office PowerPoint 2003, Jakarta: PT. Elex Media Komputindo.

Burhan Bungin, 2010, Metodologi Penelitian Kuantitatif, Jakarta: Prenada Media Group.

Daryanto, 2012, Media Pembelajaran Peranannya Sangat Penting Dalam Mencapai Tujuan Pembelajaran, Yogyakarta: Gava Media.

Deni Darmawan, 2012, Pendidikan Teknologi Informasi dan Komunikasi Teori dan Aplikasi, Bandung: PT. Remaja Rosdakarya.

Departemen Pendidikan dan Kebudayaan, 1990, Kamus Besar Indonesia Cet., $K e-3$, Jakarta: Balai Pustaka.

Departemen Pendidikan Nasional, 2008, Kamus Besar Indonesia Pusat Bahasa, Jakarta: Gramedia Pustaka Utama.

Hamdani, 2011, Strategi Belajar Mengajar, Bandung: CV. Pustaka Setia.

Iqbal Hasan, 2009, Analisis Data Penelitian dengan Statistik, Jakarta: PT. Bumi Aksara.

M. Musfiqon dan Andiek Widodo, 2015, Desain Presentasi Pembelajaran Inovatif, Jakarta: Prestasi Pustakaraya.
Made Wena, 2011, Strategi Pembelajaran Inovatif Kontemporer Suatu Tinjauan Konseptual Operasional, Jakarta: Bumi Aksara.

Muhaimin, dkk, 2012, Paradigma Pendidikan Islam, (Bandung: PT. Remaja Rosdakarya.

Muhibbin Syah, 2004, Psikologi Belajar, Jakarta: PT RajaGrafindo Persada.

Musfiqon, 2012, Metodologi Penelitian Pendidikan, Jakarta: Prestasi Pustakawan.

Pengertian dan Sejarah Microsoft Power Point, diakses dari https://irwanadigunawan4.wordpress .com/2013 /10/31/pengertian-dansejarah-microsoftpowerpoint /dalam www.google.com, pada hari Minggu, 8 Januari 2016, pukul 17.36 WIB

Riduwan, 2011, Belajar Mudah Penelitian Untuk Guru, Karyawan dan Peneliti Pemula, Bandung: Alpabeta.

Rudi Susilana dan Cepi Riyana, 2008, Media Pembelajaran, Hakikat Pengembangan, Pemanfaatan dan Penilaian, Bandung: CV. Wacana Prima.

Sharon E. Smaldino, dkk, 2011, Instructional Teachnology \& Media for Learning: Teknologi Pembelajaran dan Media untuk Belajar, Jakarta: Prenada Media Group.

Slameto, 2010, Belajar \& Faktor-faktor yang Mempengaruhi, Jakarta: PT Rineka Cipta.

Syaiful Djamarah dan Aswan Zain, 2006, Strategi Belajar Mengajar, Jakarta: PT Rineka Cipta. 